\title{
Study of Indigenous Peoples Empowerment Model in Sundanes Village
}

\author{
E. Sumiati, A. Hufad \\ Department of Non-Formal Education, Universitas Pendidikan Indonesia \\ Bandung, INDONESIA \\ dreams.miate@gmail.com
}

\begin{abstract}
Social and technological developments today did not have a significant impact to the culture of indigenous peoples in Cireundeu Village. Instead, they maintain their ancestors' cultural values and traditions in their social and economic life. The objectives of this research were to discover and explain the patterns of social and economic life in accordance to the local wisdom. The results which were obtained by an ethnographic approach, Logic Analysis Method, are: (1) The life patterns of Cireundeu society today is formed through a long stage of socialization and inheritance that it has been applied since childhood and is a fundamental need for all indigenous peoples in Cireundeu Village; (2) The society's economy system is built based on the principles of fulfilling the needs, by providing them abilities to compete with outsiders; (3) Empowerment of indigenous peoples in Cireundeu Village is based on the "by the people and for the people" principle. This principle was built based on discovering potentials to strengthen the resilience of socioeconomic. Thus, it could be an entity that has the potentialbased economy and local knowledge.
\end{abstract}

Keywords-People Empowerment, Culture, Local Wisdom, Indigenous Peoples.

\section{INTRODUCTION}

Problems of poverty, seems to have become a common phenomenon throughout the world. Therefore, poverty eradication agenda was incorporated into the agenda of the first of eight Millennium Development Goals (MDG'S) 19902015. In Indonesia context, efforts to reduce poverty today becomes very important because the World Bank has concluded that poverty in the country is not only that $10-20 \%$ of the population living in absolute poverty (extreme poverty), but also approximately three-fifths or $60 \%$ of Indonesia's population is currently living below the poverty line. However, the steps taken by the government has only been focusing on achieving poverty target without concerning the equality between socio-economic and territories. Report from Central Statistics Agency (BPS) indicated in 2013Indonesia reached the social collapse at its highest level (0.413) and will continue to increase if no immediate steps to balance the distribution of welfare, which should be considered as the right solution for building self-sufficient and prosperous communities

Therefore, there is a need for a model of community empowerment that emerged from the public in choosing the need, planning development, managing the process and maintaining it independently. Such empowerment process will build an independent society and consistent with the theory that are people centered, participatory, empowering a sustainable society (Chambers, 1995), then community empowerment is increasingly becoming a necessity in any community development effort itself.

In line with these thoughts, Kindervatter (1979), gives a clear role on the role of empowerment in order empowering process, the role of empowerment not only transform individuals, but also groups, organizations and communities. Empowerment as a process containing a broad sense, which includes increasing the knowledge, attitudes, skills and other skills development towards independence alive. Kindervatter (1979: 13) explains that; for the purposes of this study, is empowering; people gaining an understanding of control over social, economic, and / or political forces in order to improve Reviews their standing in society.

People who are able to build the environment that people are aware of the need to explore the potential of a certain area and retains local wisdom in an area with various ways and techniques to become a staple food as well as developing various preparations of local knowledge possessed, one only the local knowledge will still maintain the tradition of eating constellation (rice cassava), namely in Cireundeu Village with all its uniqueness is not only known by the public environment Cimahi, but it is well known because it has a characteristic in everyday life.

Cireundeu Village is located in the Leuwigajah District of South Cimahi Cimahi city. It comprises of 300 households and is divided into two sections of society, i.e. the "Community Cireundeu Village" and the "Indigenous Cireundeu Village". Contrary to the common societies, Cireundeu Village is almost never affected by the social upheaval that often occurs such as the high price of staple food, especially rice.

\section{THE LIFE PATTERNS OF INDIGENOUS PEOPLES}

Indigenous peoples in Cireundeu Village highly uphold his religion, culture and their customs. They have a principle "Ngindung Ka Waktu, Mibapak Ka Jaman". Which words "Ngindung Ka Waktu" is that we as indigenous peoples have the means, characteristics and beliefs of each. While "Mibapak Ka Jaman" means indigenous people in Cireundeu not closed to the development of the current era.

Moreover, indigenous people in Cireundeu Village is guided by the principle of life, namely: "Teu Nyawah Asal 
Boga Pare, Teu Boga Pare Asal Boga Beas, Teu Boga Beas Asal Bisa Nyangu, Teu Nyangu Asal Dahar, Teu Dahar Asal Kuat", which means that one might not cultivate the field but he still has rice, one might not have rice but he still has food, one might not cook but he still can eat.

The shift of the staple food of indigenous peoples in Cireundeu Village of rice into rice cassava began approximately in 1918, spearheaded by Mrs. Omah Asmanah, son of Mr. Haji Ali, followed by his brothers in the Cireundeu Village. Omah Asmanah began developing non-rice staple food, and her pioneering work was granted an award for "Food Heroes" in 1964 by the local government.

Since 1918 Indigenous peoples in Cireundeu Village has maintained the tradition of ancestry by selecting the staple food made from cassava, called rasi. Guarded tradition passed down through generations has become something that is typical of indigenous peoples in Cireundeu Village. Rasi is the symbol of the society identity and this statement is based on 1) the fact that the rasi is consumed by the entire society in Cireundeu Village, 2) indigenous people who consume the rasi because of beliefs or convictions that require eating non rice, and the non-believers in Cireundeu also consume rasi, 3) the habit of consuming rasi generally occurs due to hereditary factors as the primary socialization and because of the interaction with other people or the environment.

In addition, local wisdom is still very strong which is always applied to the environment of indigenous peoples in Cireundeu Village. Concern and his love for nature and the environment to be a part of the lives of citizens, as well as ancestral advice in order to maintain and preserve nature and the environment

The belief systems of indigenous peoples in Cireundeu namely "Sunda wiwitan", known by Prince Madrais (Cigugur) since 1918. Until now, said Abah Emen, philosophy of life Cireundeu has not changed much since the last decades. They still hold the moral teachings about how to carry self in life, as they must cultivate everything that has been a tradition in the ancestor.

The management of existing customary in the indigenous village in Cireundeu Village chaired by an indigenous leader, called the Elders. Elders could mean as the most important and has the duty to preserve and maintain the tradition inherited by ancestry. In performing its duties, Elders assisted by Pangampih. Pangampih served as more people use the language of symbols "leuwih ngais" information. Pangampih assisted by panitren who serves as a liaison between nonoman or youth and the indigenous peoples.

The majority of indigenous people in Cireundeu are farmers. They manage agricultural land which still dominates the area of Cireundeu Village. Their daily lives are dominated by the agrarian life pattern. Most agricultural products, especially the harvest in large quantities, are processed both for own consumption and for sale. People are much more comfortable to survive in its region rather than out of the Cireundeu village, and there are some young people who choose to seek employment outside as factory workers. But, they never forget to take the time to community activities.
The language used by the indigenous people in Cirendeu Village consist of spoken and written language. The spoken language used in everyday namely Sundanese dialect which is different from the Sundanese language in general. Formal language or the Indonesian commonly used in schools or when there are guests visiting who do not understand the Sundanese language. Whereas written language using ancient Sundanese language. Indigenous peoples in Cireundeu Village communicate using the polite Sundanese language.

In the field of art, indigenous people in Cireundeu Village develop various kinds of Sundanese dance and song, martial arts, karinding, gamelan, sculpture and woodcarving. All local arts Sundanese it, indigenous peoples in particular has the youth learn from childhood to adulthood, the elders bring in teachers from other indigenous villages, namely Brass to teach the arts.

Infrastructure in Cireundeu Village with an area of settlement 5 hectares, there are several support buildings such as Bale (for indigenous peoples) located centrally in the middle and mosques (for community Ordinary or Muslim) which is located next to the village as a place of worship, in Cireundeu Village. There are 2 Elementary Schools each consists of 6 class rooms and one office. Iin addition to general education facilities, there is also a Learning Center the place held in "Bale saresehan".

From the historical and cultural perspective, the pattern of life of indigenous peoples Cireundeu Village is adhered to and complied with a habit of living in his life, the pattern of habits that will become a necessity of human life.

The above statement is consistent with the theory put forward by Abraham H. Maslow (1970, in Sudjana, 187: 2004) which describes five levels that must and can be fulfilled by humans in maintaining and developing the basic necessities of life, namely, the need for security, the need for a sense of owns and affection, the need for respect and selfactualization needs. Maslow gave the hypothesis that after satisfying the needs of individuals at the grassroots level, the individual will satisfy the needs of the next level. If at the highest level but basic needs are not satisfied, then the individual can return to the previous level needs.

Therefore, the life patterns of Cireundeu society today is formed through a long stage of socialization and inheritance that it has been applied since childhood and is a fundamental need for all indigenous peoples in Cireundeu Village.

\section{THE SOCIETY'S ECONOMY SYSTEM}

The economic system of the indigenous peoples in Cireundeu Village is to utilize the available natural resources in the form of local knowledge of agriculture and animal husbandry. Likewise, most Cireundeu villagers are farmers and ranchers. This fact leads the local economy to be very good and lower poverty levels and conducted empowerment efforts.

Interestingly, the communities begin to involve in the processing of cassava. There are a group of farmers and a group of home industry as well as young indigenous peoples in Cireundeu Village utilize cassava, from the roots to leave, 
into various dishes. Cassava's roots can be processed into 25 types of processed foods, such as eggroll with 6 miscellaneous taste, cheese sticks with 2 different flavors, ladyfingers biscuits, bean cake, ranggining, tape pearl, dry cireng with 2 different flavors, peanut brittle, saroja, rasi, and nastar (cookie with pineapple jam filling). The trunk can be utilized as a seed. The leaf can be used as fresh vegetables or a vegetable and used as fodder. Finally, the skin can be made into processed foods, usually used as lodeh (mix vegetable soup) or jerky cassava peel. The processed food are not only for self consumption, but also are sold to visitors who come to Cireundeu Village as a souvenir.

Production activities of indigenous peoples in Cireundeu Village is a process of transforming inputs into outputs so that the value of such goods increases. Input can be in the form of cassava as a raw material used in the production process, and outputs are goods or services which is derived from a production process in the form of processed products which can generate more revenue from raw materials.

Distribution activities of indigenous peoples Cireundeu Villages basically a bridge is essentially an intermediary between the manufacturer of the home industry and consumer groups are guests who come and people around who buy goods in the form of processed cassava. And not through intermediaries, namely Broker can be classified into two categories, namely; Agent middlemen and intermediaries. From the marketing side of the indigenous people in Cireundeu Village done on guests coming and society around the course with limited resources owned by Cireundeu Village.

In ethnography on an objective system of public economy seen from the production, distribution and consumption to increase the community's economy seen from the pattern of life and means of supporting everyday life.

According to Kuncoro (1997: 131) that the population of these countries are poor because rely on the agricultural sector which is a subsystem, which is the traditional production method, which is often accompanied by apathy towards the environment.

Based on the above theory, the indigenous people of Cireundeu Village not apply production system in the rural economy generally is still characterized by the orientation of agricultural raw materials low value added (already oriented end products of high added value), the technology used is not outdated (already based on the results of recent research), with the agribusiness program that aims to produce agricultural products of high economic value has shown success by applying the model Agroindustry ongoing in the Cireundeu Village form of processing diversified food products made from cassava.

Besides the need to build a society that focuses on economic sectors aimed at enabling the public to improve the welfare of the population through the growth of this sector, and also to reduce the level of poverty. The result of Garry Field's study (1980, in Sudjana, 2004: 264) shows that economic growth can significantly reduce poverty.
Thus, it can be said that the community empowerment by itself is centered on economics because the main goal is to grow the society's independence. Economy stimulates the community to create new and high value innovations and to generate revenue that can sustain life in the future.

From the statement it would appear a creative economy coming out of the community itself means that in the new economic era which intensifies information and creativity by relying on the ideas and stock of knowledge of Human Resources (HR) as the main production factor in their economic activities. The structure of the world economy undergoes a rapid transformation along with economic growth, from which was natural resources-based to the human resource-based and from the agricultural era to the industrial and information age.

\section{INDIGENOUS PEOPLES EMPOWERMENT MODEL IN CIREUNDEU ViLlaGE}

The phenomena that exist in the process of empowerment of indigenous peoples of Cireundeu in maintaining local wisdom used the theory of Logic Model Development Frechthling by Frechtling (2007), which explains that the model of community empowerment is a method illustrates one form the basic logic model in the form of a sequence of activities implemented, and how the relationship between inputs, outputs with the results. The steps are input, output (activities and participation), and outcomes.

Indigenous peoples of Cireundeu with local knowledge that it manages, there are some groups that are divided into several groups ranging from farmers' groups, youth groups (art) and home industry group.

By having the groups above, Cireundeu Villages able to perform the empowerment process, assisted by several parties with no cause and effect, many government agencies and non-government eager to promote Cireundeu to known and serve as an example to the wider community, by providing training, counseling and assistance in the form of goods: the dryer from the municipal government working with UNPAD, help mince machine cassava PEMKOT working with UNPAD, health counseling from the health department, and counseling of rasi transformation from P2TPKP dent.

Counseling, training, dialogue and action are used as a means of empowerment. It is intended that the process of exchange of information, knowledge and experience as well as the negotiation process among citizens to create change. Dialogue is going on Indigenous Village is a form of dialogue between the facilitators, giving the material (the elder) youth group as a group initiative, and indigenous people in Cireundeu Villagers. Dialogue is intended that the exchange of information in both directions or more. While counseling is aimed at the provision of information and experience from the source to the learners, the more one-way, but question and answer session remains open during counseling or training. Actions in the implementation of collective action become resources for collective action in the future.

The role of the Elders, especially from the panitren, Abah Asep is very important. He introduced Cireundeu 
Villages to the public Cireundeu Villages until in 2005 until now can be known by getting awards obtained. Based on the pattern of activity the provision of information on it will be easier the information provided and obtained by the indigenous people of Cireundeu Village, people will be more proactive in any activity or activity that is ddan act in accordance with their respective roles.

The success of empowerment in society is inseparable from the role of theelders, the role of the youth of any successful group of farmers and indigenous peoples mothers Cireundeu Village, in the management of the rasi that are intended for outdoor community managed by some young people.

The principle is still held by the indigenous people of Cireundeu Village that will always share with other people to make independent Indonesian society does not depend on only one staple. Indigenous peoples Cireundeu villages not affected by the social upheavals that occur or circumstances State today, like eating rice for the poor (Raskin) indigenous village Cireundeu never feel it, and obviously does not depend on the current government.

Based on the logic models above shows the situation of indigenous peoples in Cireundeu Village having a cultural values are maintained community that originated from economic hardship, with maintain traditions of the ancestors by way elkulturasi cultural values, becomes a habit instilled since childhood by the family, then made a requirement The fundamental in life and have local knowledge is maintained in the form of natural resources in the form of cassava is processed into constellations and made other preparations innovation.

As for priorities in life are guarded by instilling the values of philosophy of life and memory of history or do not forget the history with the clear purpose in life and every situation and priorities which they have then they form a pattern of empowerment that begins from the input, output already described above, who came to the outcomes achieved from short-term, medium-term and long-term.

If seen from the outcome of an impact felt by the various parties teutama Cireundeu indigenous village itself, people who have local knowledge of others and the outside community that is interested in the lifestyle of the people and governments in developing empowerment programs.

According Kartasasmitha (1996: 70) states that "Empowering people is an effort to improve the dignity of our society in the present conditions are not able to escape from the trap of poverty and underdevelopment. In other words, is to enable and empower the community's independence ".

Empowerment of indigenous peoples in Cireundeu Village is based on the principle of, by, and for the community. The principles on the basis of excavation potentials by strengthening socio-economic resilience, so that could be an entity that has the potential based economy and local knowledge.

Based on the above explanation that in accordance with the objective to achieve community empowerment empowered, prosperous and self-empowerment are already visible pattern on the principle of, by and for the community.. A model of community empowerment in retaining local knowledge on indigenous Cireundeu villages is presented in the below schema.

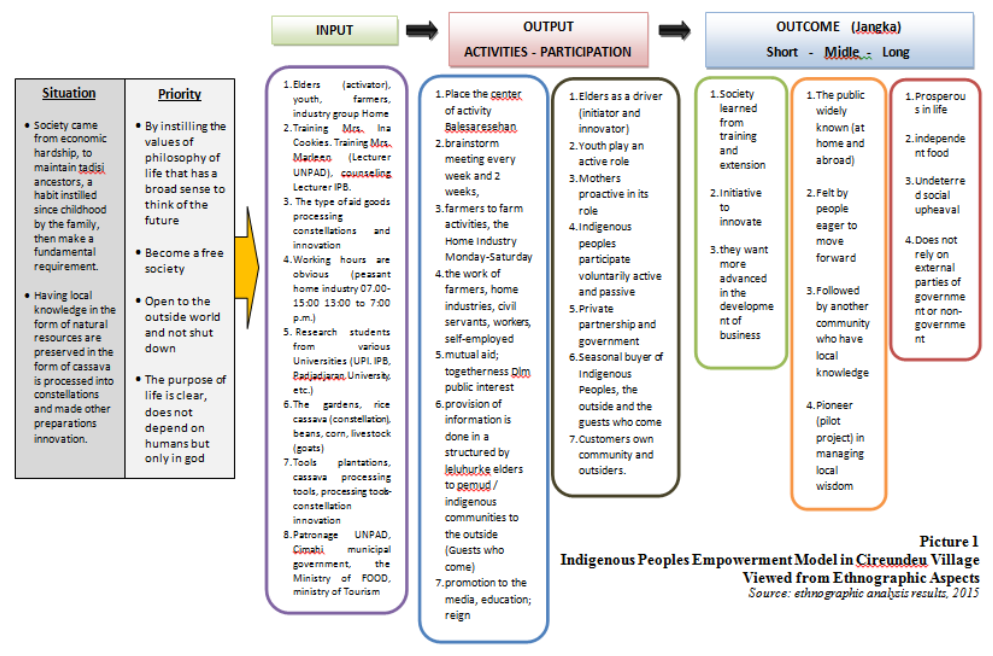

\section{REFERENCES}

[1] Kartasasmita, Ginandjar. (27 Mei 1995). Pemberdayaan Masyarakat: Sebuah Tinjauan Administrasi; Pidato Pengukuhan Jabatan Guru Besar dalam Ilmu Administrasi pada Fakultas Ilmu Administrasi Pemangunan Universitas Brawijaya; Malang.

[2] Jim Ife dan Frank Tesoriero. (2008). Community Development. Penerjemah Sastrawan Manulang dkk. Jogjakarta. Pustaka Pelajar.

[3] Mardikanto, Totok. (2012). Pemberdayaan Masyarakat Dalam Perspektif Kebijakan Publik. Bandung. Alfabeta.

[4] Prijono, O.S. dan Pranarka, A.M.W., (1996). Pemberdayaan: Konsep, Kebijakan dan Implementasi. Penerbit Centre for Strategic and International Studies, Jakarta.

[5] Sudjana, D. (2006). Pendidikan Nonformal: Wawasan, Sejarah Perkembangan, Filsafat, Teori Pendukung, Asas. Bandung: Rosda.

[6] Spradley, P., (2007). Metode Etnografi. Yogyakarta: Tiara Wacana.

[7] Sumodiningrat, G. (1999). Pemberdayaan Masyarakat dan Jaring Pengaman Sosial Jakarta: Gramedia. 